BOEKBESPREKINGEN

Dr. C. van Dam

\section{BESLISSEN IN ONZEKERHEID}

Bedrijfseconomische Monographieën 51 1973, 198 pagina's, gebonden $f 38,50$.

\section{door Drs. J. A. Hartog}

Zowel uit de titel van het boek als uit de naam van de serie waarin het is verschenen blijkt, dat men het moet zien als een bijdrage tot de decisietheorie; een zeer vitale en nog jonge tak van de toegepaste economie, waaraan de namen van grote geleerden als Von Neumann en Savage verbonden zijn. Van Dam zelf doet dit kennelijk ook, daar hij op verschillende plaatsen zijn theorie stelt tegenover het monumentale werk van Von Neumann en Morgenstern.

Nieuwsgierig geworden gat men natuurlijk proberen te bepalen, waaruit Van Dam's theorie bestaat. En dan blijkt het al zeer spoedig, dat hij geen enkele bijdrage van theoretische aard levert, tenzij men zo welwillend is de twee pagina's waar Van Dam de techniek beschrijft, waarmee hij een puntenwolk doet samenklappen tot een ééndimensionale kromme, als een theorie te beschouwen.

De decisietheorie is een omvangrijk apparaat. Van Dam's boek raakt hiervan slechts één onderdeel, nl. de zgn., indifference function for money". Het bestaat uit een teschrijving van een onderzoek waarbij aan 143 vrij vaag aangeduide personen gevraagd wordt hoe hoog zij de geldbedragen achten die equivalent zijn met een groot aantal loterijen. Met behulp van die reeksen antwoorden construeert Van Dam een kromme voor ieder van zijn proefpersonen, die hij ziet als een verbetering van de reeds vermelde ,indifference function for money". En dat is alles. Hij zegt bijv. nergens wat men met zijn krommen kan doen. In de decisietheorie wordt de "indifference curve for money" gebruikt voor het bepalen van dat gedrag dat in de gegeven omstandigheden optimaal is. Van Dam is in ieder geval zo verstandig dat hij niet zegt, dat zijn ,"nutilekurve" zo gebruikt kan worden.

Het wekt dan ook verbazing dat op de omslag van het boek door de uitgever wordt geschreven: „Toepassing van zijn theorie schept grote mogelijkheden... zeer duidelijke richtlijnen voor beslissingen op alle niveaus kunnen worden gegeven." Nergens in zijn boek zegt van Dam hoe hij deze richtlijnen denkt af te leiden. Hij kan dit ook niet zeggen.

ma $a$ blz. 222
In dit verband is het merkwaardig dat verschillende malen in het boek gesteld wordt dat niet bestudeerd word thoe mensen zich zouden moeten gedragen, maar dat slechts beschreven wordt hoe zij zich in feite gedragen. En dat is binnen het kader van de decisietheorie volmaakt irrelevant. Het is zonder meer duidelijk dat ,when decision making is left solely to unguided judgement, choices are often made in an internally inconsistent fashion".

Als het boek dan niet gezien kan worden als een bijdrage tot de decisietheorie is het misschien zinvol het te zien als een studie in beschrijvende psychologie. In de Penguin Modern Psychology serie bijv. is een door Ward Edwards en Amos Tversky verzamelde bundel opstellen verschenen onder de naam "Decision Making”.

Maar ook vanuit deze gezichtshoek kan het boek aan ernstige kritiek onderworpen worden.

Zo beschrijft Van Dam zijn experimentele techniek wel, maar hij verdedigt haar niet. Zijn techniek bestaat uit het stellen van reeksen vragen. Velen menen dat antwoorden op dergelijke vragen geen informatie verschaffen over feitelijk gedrag. $Z_{\mathrm{ij}}$ ontwerpen dan experimenten die mensen plaatsen in een onzekere situatie, zodanig dat het mogelijk is hun gedrag te analiseren. Dikwijls zijn deze experimenten zeer ingenieus, wat de verslagen uitermate boeiend doet zijn. Uit Van Dam's literatuurlijst moet men afleiden, dat hij van het bestaan van dergelijke onderzoekingen op de hoogte is. Het zou interessant $z$ ijn geweest te vernemen waarom hij meent, dat zijn ondervraagtechniek superieur is.

Voor mij als statisticus is het onbegrijpelijk dat Van Dam zich niet voldoende realiseert, dat als een persoon een gehele dag vragen beant woordt, terwijl aan die antwoorden voor hem geen enkele consequentie verbonden is, er in die antwoorden een element van willekeur zal ontstaan. Op pag. 106 zegt hij wel dat deelnemers, die twee keer met dezelfde vragen worden geconfronteerd zich de tweede keer consistenter gedragen, maar hij laat het bij deze opmerking en gaat niet in op de gevolgen van dit feit voor zijn analyse.

Samenvattend is $m i j n$ oordeel dat dit boek een slecht boek is; het is jammer dat het gepubliceerd is in de reeks Bedrijfseconomische Monographieën. Ik meen dit oordeel onverbloemd te moeten uitspreken omdat in een land als $\mathrm{Ne}$ derland, waarin de literatuur over de decisietheorie slechts weinig ontwikkeld is, het boek ernstige misverstanden kan wekken. Ik bevind mij daarbij wel in volkomen andere omstandigheden dan Oscar Wilde toen hij schreef: „On an occasion of this kind it becomes more than a moral duty to speak one's mind. It becomes a pleasure." 


\section{DUBBELE HEFFING BIJ BESLOTEN EN} OPEN VENNOOTSCHAPPEN

Bespreking van - en beschouwingen naar aanleiding van - het proefschrift van Dr. K. van der Heeden, verschenen als nr. 4 in de serie Geschriften van het fiscaal-economisch instituut van de Erasmus Universiteit te Rotterdam bij Kluwer-Samsom 1973.

\section{door Dr. L. Roeloffs}

Het proefschrift waarop Van der Heeden vorig jaar promoveerde tot doctor in de economische wetenschappen aan de Erasmus Universiteit te Rotterdam heb ik met bijzondere belangstelling gelezen. Deze belangstelling vloeit, behalve uit de omstandigheid, dat ik mijzelf 10 jaar geleden diepgaand, althans langdurig met hetzelfde onderwerp heb beziggehouden, tevens voort uit de voortdurende actualiteit van de stof, welke actualiteit helaas chronisch lijkt te worden.

Van der Heeden verdeelde zijn geschrift in 3 delen, waarvan deel $I$ is gewijd aan het onderscheid tussen besloten en open vennootschappen. In dit deel heeft de schrijver aan de gebruikelijke indeling van besloten vennootschappen, wier aandeelhouders nog duidelijk ondernemers zijn tegenover de open vennootschappen, wier aandeelhouders nog slechts beleggers zijn, een tussencategorie toegevoegd, n.l. de ontsloten vennootschappen met zowel ondernemende als beleggende aandeelhouders, de ontsloten vennootschappen, en deze drie vennootschapstypen vervolgens in de breedte en in de diepte geanalyseerd. Deze uitvoerige analyse naar economische, fiscale en vennootschapsrechtelijke criteria, leidde de schrijver tot de conclusie, dat de mate van betrokkenheid van de aandeelhouders geen relevante aanknopingspunten kan opleveren om als uitgangspunten te dienen voor een zinvol onderscheid in de mogelijkheden tot opheffing of matiging van dubbele belastingheffing.

Enerzijds kan men zich afuragen of een zo uitvoerige en diepgaande studie nodig is om tot deze m.i. geenszins verrassende conclusie te komen. Anderzijds dient de vraag te worden opgeworpen of $\mathrm{Van}$ der Heeden inderdaad een doodlopende weg bewandelde, althans of er in het verkende vennootschapsland toch niet een tracé gevonden had kunnen worden om op basis van een verschil in betrokkenheid van de aandeelhouders relevante criteria met betrekking tot een matigingsbeleid ten aanzien van de dubbele heffing aan te wijzen. Ik doel hierbij met name op een uitbreiding van de deelnemingsvrijstelling tot de z.g. deelnemingsintegratie, waarbij de deelnemingsvrijstelling, thans slechts van toepassing tussen rechtspersonen onderling, wordt uitgebreid tot alle bedrijfsmatige deelnemingen, dus ook tot die gevallen waarbij particuliere ondernemers bedrijfsmarig aandelen bezitten in vennootschappen of bedrijfsmatig lid zijn van coöperatieve verenigingen of verenigingen op coöperatieve grondslag. $V$ ia de deelnemingsintegratie wordt het kleine ondernemers op zinvolle wijze mogelijk gemaakt - hetzij vennootschappelijk, hetzij coöperatief - in grotere verbanden (partieel) samen te werken, zonder te worden getroffen door een discriminatoire dubbele belasting. Aan deze specifieke vorm van vermijding van dubbele belasting van ondernemingswinsten, waaraan ik behalve in mijn dissertatie van 1964 (blz. 125-130), uitvoerig aandacht wijdde in mijn boek „De Coöperatie, maatschappelijk en fiscaal beschouwd" (blz. 83-86), is Van der Heeden - m.i. ten onrechte - geheel voorbijgegaan. Hetzelfde geldt voor mijn suggestie om een aandeelhouder-ondernemer, een aandeelhouder met aanmerkelijk belang daaronder begrepen, de keuze te laten om zijn aandelenbezit al dan niet als bedrijfsmatig aan te mer ken.

Van der Heeden komt aan een beoordeling van deze partiële oplossing niet toe, omdat hij in deel $\mathrm{Il}$ in het algemeen pleit voor opheffing van dubbele belasting. M.i. behoeft en behoort deze algemene conclusie geen reden te zijn om partiële oplossingen buiten beschouwing te laten. De dubbele belasting wordt het sterkst gevoeld binnen de ondernemingssfeer en is $\mathrm{m}$. $\mathbf{i}$. zo evident discriminerend tegen samenwerkende kleine ondernemers, dat - los van de alge mene wenselijkheid en modaliteiten van algehele opheffing of matiging van dubbele belas ting - een partiële ingreep ten gunste van de deelnemingsintegratie op zijn plaats zou zijn. Hierbij dient tevens bedacht te worden, dat de deelnemingsintegratie leidt tot opheffing van dubbele belasting, terwijl het ook Van der Heeden duidelijk is, dat in het algemeen slechts matiging tot de reële mogelijkheden behoort.

Met het aan deel II ten grondslag liggende Leitmotiv, n.l. dat de vraag of - en zo ja, in welke omvang - dubbele belasting moet worden gematigd, in eerste instantie een kwestie van verdelende rechtvaardigheid is, verklaar $i k \mathrm{mij}$ bij voortduring akkoord. Van der Heeden heeft echter meer pijlen op zijn boog om de dubbele belastingheffing te veroordelen. De econo- 
mische neutraliteit t.o.v. de rechtsvorm van de onderneming eist, los van de verdelende rechtvaardigheid, een logisch verband tussen $V_{p b}$. en I.B., o.a. in die zin, dat gestreefd moet worden naar een gelijktrekken van het $V$ pb.-tarief en het hoogste I.B.-tarief, waarna aan dubbele belasting van dividenden iedere grond ontvalt (blz. 85). Ook economische neutraliteit t.o.v. de financiering van een onderneming eist logisch-dwingend een gelijke behandeling van geleend geld en in de vorm van aandelenkapitaal ter beschikking gestelde middelen. Voor een als volkomen zelfstandig aangemerkte onderneming, welke voor haar winst zelfstandig wordt belast, vormt dividend evenzeer een kostenbestanddeel als rente van geleend geld. Restricties op deze economische realiteit, zoals tot een primaire vergoeding over het gestorte aandelenkapitaal, worden door Van der Heeden terecht gelaakt.

Van der Heeden komt aan het slot van Hoofdstuk 7 tot de conclusie, dat de dubbele belasting het zwaarst drukt op de winst van ont sloten vennootschappen, in iets mindere mate op de winst van open vennootschappen en niet drukt op de in economisch besloten vennootschappen behaalde winst. Hoewel deze con. clusie globaal wel met de realiteit zal overeenstemmen, wil ik niet nalaten op te merken, dat in zeer vele gevallen deze realiteit een door de (dreiging van) dubbele belasting vertekend beeld geeft. In een aantal gevallen zou bij besloten vennootschappen en in vele gevallen bij ontsloten vennootschappen (meer) dividend worden uitgekeerd als de fiscale situatie niet als prohibitief of als bezwarend zou worden aangevoeld. Deze problematiek ligt bij ontsloten vennootschappen inderdaad het moeilijkst, waarbij de ,ontsloten" aandeelhouder in de strijd om salaris en tantièmes enerzijds, dividend anderzijds, veelal, n.l. zolang de aandeelhouders-ondernemers de macht in handen hebben, aan het kortste eind trekt.

Van der Heeden besluit deel II met het uitdiepen van een drietal zogeheten ideaalsystemen, t.w. aandeelhouders-winstbelasting, ondernemings-winstbelasting en winstgerechtigdenbelasting, een keuze uit een rijke scala van mogelijkheden, welke mij niet bijster aanspreekt, omdat de genoemde systemen geenszins ideaal blijken, zij het dat de verwerking en "Verwertung" van deze systemen, de negatieve conclusies van de schrijver ten spijt, wel respect afdwingen.

Van den Tempel heeft in zijn bespreking van het onderhavige proefschrift in W.F.R., no.
5136 van 7 juni 1973 scherpe critiek geuit op de toetssteen van Van der Heeden, n.l. de verdelende rechtvaardigheid en hij verwijt de schrijver, dat hij, aldus handelende, het gelijkheidsbeginsel te eenzijdig hanteert en hierbij twee essentiële aspecten, t.w. de internationale en de belastingtechnische te kort doet. Vooropstellende, dat de E.G.-nota van Van der Tempel, door onze toenmalige regering dankbaar en klakkeloos overgenomen, mij geenszins overtuigend voorkomt, heb ik begrip voor de critiek van $\mathrm{Van}$ den Tempel, die in een uitvoerig gedocumenteerd betoog gepleit heeft voor het klassieke stelsel van dubbele belasting. M.i. had Van der Heeden zich meer moeite behoren te getroosten om het betoog van Van den Tempel te analyseren. De conclusie van Van den Tempel, dat verrekeningssystemen mank gaan aan internationale discriminatie, verdiende meer aandacht en critiek. Het is overigens bepaald niet zo, dat Van der Heeden de door Van den Tempel genoemde criteria geheel verwaarloosd heeft.

In deel 111 bespreekt Van der Heeden enige methoden, welke kunnen leiden tot opheffing van de dubbele belasting en wel, zoals hij in de inleiding stelt, in overeenstemming met het beginsel van non-discriminatie in het nationale en internationale belastingrecht. Tegenover elkaar worden gesteld het gedifferentieerde tarief en de verrekeningssystemen. Voorzoveel nodig heeft Van der Heeden (hoofdstuk 11) nog eens duidelijk gemaakt, dat het in West-Duitsland vigerende gedifferentieerde tarief bijzonder onpraktisch is en in wezen in de internationale verhoudingen onhanteerbaar.

Om verschillende redenen ben ik met $\mathrm{Van}$ der Heeden van oordeel, dat opheffing of matiging van dubbele belasting bij de aandeelhouder dient te geschieden, in de eerste plaats omdat de economische neutraliteit internationaal het best tot haar recht komt bij een zelfstandige belasting van de winst van een onderneming door het land waar die onderneming is gevestigd. Indien men van oordeel is, dat met betrekking tot de uitgedeelde winst matiging behoort te worden betracht bij de belastingheffing van de aandeelhouder, dan ligt het voor de hand, dat deze matiging wordt aangebracht door het land, dat de andeelhouder voor het dividend belast. $\mathrm{Bij}$ dit - m.i. juiste - uitgangspunt heeft ieder land het zelf in de hand om discriminatie van zijn onderdanen te vermijden. Deze gedachte is niet vreemd, immers ook met betrekking tot de in het land van vestiging geheven dividendbelasting, volgens verdrag veelal $15 \%$, 
geschiedt verrekening met de I.B. van de aandeelhouder in diens woonstaat. Uitgangspunt van de onderhavige problematiek is de cardinale en prealabele vraag hoeveel belasting een land wil of mag heffen over de winst van een in dat land gevestigde onderneming. Voor Europa is het antwoord: ongeveer $50 \%$ Vpb., $15 \%$ Dividendbelasting voor beleggingsdividenden en $5 \%$ Dividendbelasting voor deelnemingsdividenden.

Het vertekeningsstelsel vertoont, los van de vraag hoe ver men met matiging van de dubbele belasting wil gaan, een aantal, door Van der Heeden behandelde, varianten, t.w.:

1 Verrekening van binnenlandse $\mathrm{Vpb}$. voor binnenlandse aandeelhouders;

2 Verrekening van binnenlandse $\mathrm{Vpb}$. voor binnenlandse en buitenlandse aandeelhouders;

3 Verrekening van binnen- en buitenlandse $\mathrm{Vpb}$. voor binnenlandse aandeelhouders;

4 Verrekening van binnenlandse en geforfaiteerde buitenlandse $\mathrm{Vpb}$. voor binnenlandse aandeelhouders.

De voorkeur van Van der Heeden gaat uit naar het 4 e systeem. Met deze voorkeur kan ik mij, na toetsing van de internationale aspecten, t.w. non-discriminatie, afbakening van de belastingsouvereiniteiten, de betalingsbalans, de E.G. en de uitvoeringstechniek, verenigen. Uit de beschouwingen van Van der Heeden blijkt duidelijk, dat over deze materie, met name in de E.G. nog lang geen overeenstemming bestaat. Het wachten is thans op het voorstel van de nieuwe Europese Commissie, waaromtrent reeds bekend is, dat deze Commissie voorstand- ster is van een verrekeningssysteem ${ }^{1}$ ). Van den Tempel (zie W.F.R., no. 5136) verwijt de schrijver, dat de aan verrekeningsmethode 4 ten grondslag liggende gedachte onvruchtbaar is en dat een grondig onderzoek niet achterwege had mogen blijven. Het belangrijkste bezwaar van Van den Tempel, dat in het geponeerde stelsel dividend lichter wordt belast dan overig inkomen, is in wezen onjuist. Als de gehele winst van een vennootschap met $50 \% \mathrm{Vpb}$. wordt getroffen, de resterende $50 \%$ met progressieve I.B., ofwel - in I.B.-termen vertaald - de halve winst met $100 \%$ wordt belast, de andere helft met progressieve I.B., is een matiging van de I.B. bij de aandeelhouder wel op haar plaats. Dat de presentatie hic et nunc nadelen oplevert, zie ik niet als een werkelijk bezwaar. Van den Tempel wijst eveneens op het gevaar van misbruik, bijv. het transformeren van andere inkomsten in dividendinkomen, terwijl ook de forfaitaire vaststelling van de buitenlandse $\mathrm{V} p \mathrm{~b}$. hem zwaar op de maag ligt. Dat nadere studie omtrent de $4 \mathrm{e}$ methode gewenst is, ligt voor de hand. Voor mij staat, anders dan voor Van den Tempel, geenszins vast, dat de alsdan opdoemende moeilijkheden niet opgelost zouden kunnen worden.

Ik acht het een verdienste van Van der Heeden, dat hij in een helder en prettig leesbaar betoog een materie onderhanden heeft genomen, waarmee de fiscale wereld, met name in de E.G., in het reine moet komen.

1) Zie Van den Tempel, W.F.R., 21-1-1974, no. 5164 . 